\title{
ANALYSIS OF THE POTENTIAL BANANA PRAWN (Penaeus merguiensis) IN THE NORTHERN WATERS OF REMBANG REGENCY
}

\author{
Analisis Potensi Sumber Daya Udang Putih (Penaeus merguiensis) di Perairan Utara Kabupaten \\ Rembang \\ Oleh: \\ Mohamad Fatikhul Umam¹, Agus Suherman²*, Kukuh Eko Prihantoko ${ }^{3}$ \\ 1 Departemen Perikanan Tangkap, Fakultas Perikanan dan Ilmu Kelautan, Universitas Diponegoro.mfatikhulumam@gmail.com \\ 2 Departemen Perikanan Tangkap, Fakultas Perikanan dan Ilmu Kelautan, Universitas Diponegoro. lpgsuherman2@gmail.com \\ ${ }^{3}$ Departemen Perikanan Tangkap, Fakultas Perikanan dan Ilmu Kelautan, Universitas Diponegoro. \\ kukuhekoprihantoko@lecturer.undip.ac.id \\ *Correspondence:lpgsuherman@yahool.comdanlpgsuherman2@gmail.com
}

Diterima: 22 Juni 2021; Disetujui: 13 Agustus 2021

\begin{abstract}
This study aims to describe the characteristics of mini bottom trawl fishing gear and fishing season, as well as to estimate the stock density and sustainable potential of banana prawn (Penaeus merguiensis), in Rembang Regency. This study was conducted from September to October 2020, in the Northern Waters of Rembang Regency, with an area of $1409.7 \mathrm{~km}^{2}$, using both primary and secondary data. Primary data was collected directly from observations, measurements, and interviews with fishermen, while secondary data, including data on the number and types of fishing gear, as well as production and production values, was obtained through a literature review. The results of the study found that banana prawn in the northern waters of Rembang Regency was caught using two types of fishing gear, and these are sotok/mini bottom trawls and trammel nets. The total length of mini bottom trawl in this study are $15.77 \mathrm{~m}, 16.5 \mathrm{~m}, 20.44 \mathrm{~m}$, and $25.2 \mathrm{~m}$. The fishing season for banana prawn is from June to September The average stock density value is $16.22 \mathrm{~kg} / \mathrm{km}^{2}$ (range 4.37 to $41.14 \mathrm{~kg} / \mathrm{km}^{2}$ ), the Cmsy value is $2.625 \mathrm{~kg}$, the Emsy value is 4.172 trips and the average utilization rate is $44 \%$ (range 23 to $82 \%$ ).
\end{abstract}

Keywords: Rembang, banana prawn, stock density, and MSY.

\section{ABSTRAK}

Penelitian ini bertujuan untuk menggambarkan karakteristik alat tangkap arad; musim penangkapan udang putih (Penaeus merguiensis); menentukan kepadatan stok udang putih (Penaeus merguiensis); mengestimasi potensi lestari udang putih (Penaeus merguiensis) di Kabupaten Rembang. Penelitian ini dilaksanakan pada bulan September hingga Oktober 2020 di Perairan Utara Kabupaten Rembang dengan luas wilayah $1409,7 \mathrm{~km}^{2}$, menggunakan data primer dan data sekunder. Data primer diperoleh melalui observasi, pengukuran, dan wawancara dengan nelayan, sedangkan data sekunder berupa data jumlah dan jenis alat tangkap, serta nilai produksi dan produksi diperoleh melalui studi pustaka. Hasil penelitian menunjukkan bahwa udang putih (Penaeus merguensis) di Perairan Utara Kabupaten Rembang ditangkap menggunakan dua jenis alat tangkap yaitu sotok/ arad (mini bottom traw/) dan jaring gondrong atau trammel net. Ukuran alat tangkap Arad yang digunakan dalam penelitian ini masing-masing berukuran $15.77 \mathrm{~m}, 16.5 \mathrm{~m}, 20.44$ $\mathrm{m}$, dan $25.2 \mathrm{~m}$. Musim penangkapan udang putih terjadi pada bulan Juni sampai dengan September. Nilai rata- kepadatan stok sebesar 16,22 kg/km² (range 4.37 hingga $41,14 \mathrm{~kg} / \mathrm{km}^{2}$ ), nilai Cmsy 2.625 
$\mathrm{kg}$, nilai Emsy 4.172 trip serta nilai rata-rata tingkat pemanfaatan sebesar 44\% (range 23 hingga $82 \%)$.

Kata kunci: Rembang, Udang Putih, Kepadatan Stok, and MSY.

\section{INTRODUCTION}

In Rembang Regency, fisheries and marine are the key sectors and it is located in Indonesia Fisheries Management Area 712, known as WPPNRI 712. Based on the Decree of the Minister of Maritime Affairs and Fisheries, WPPNRI 712 covers the Java Sea, and is a strategic fishing area in Indonesia, with an estimated potential fish resources of 981,680 tons/year (Ma'mun et al., 2018). Data from Department of Maritime Affairs and Fisheries of Rembang Regency (2020a,b) stated the total production in 2015, 2016, and 2018 was $2,100 \mathrm{~kg}, 676 \mathrm{~kg}$, and $596 \mathrm{~kg}$, worth IDR. 84,180,000.00; IDR 29,400,000.00 and IDR 59,780,000.00, respectively.

Banana prawn (Penaeus merguiensis) is a capture fishery product with high economic value and is highly sought by most consumers, as indicated by the high price range of IDR. 80,000.00-100,000.00 per kilogram (Solihin et al., 2011; Wijayanto et al., 2013; Badriuzzaman and Yulianto, 2014; Sa'adah and Milah, 2019). These species are generally caught using trawl, trammel net, danish seine, dogol net, guiding barrier (belat), and sero (Subani and Barus 1988).

In Java, the price of this prawn is quite varied, ranging from IDR. 50,000-IDR. 55,000 per kilogram for size 100 (i.e. 100 prawns per 1 kilogram), in 2019 and early 2020, on the Island of Java, except the Banten area. However, the prices surged with prices of IDR. $50,000-$ IDR. $55,000 / \mathrm{kg}$ for size 100, IDR. 60,000 -IDR. $65,000 / \mathrm{kg}$ for size 70 , and above IDR. $75,000 / \mathrm{kg}$ for size 40 , recorded by midMay. Subsequently, the prices continued to fluctuate, with a downward trend recorded at the end of October (Zulfikar, 2020). According to Manadiyanto et al., (2017a), the price of banana prawn (Penaeus merguiensis) was IDR. 80.000,00 - IDR. 100,000.00, IDR. 60,000 - IDR. 80.000,00, and IDR 50,000.00 IDR 80,000,00, per kilogram, in Pati, Gresik and Demak, respectively.

The fishing gear used by fishermen in Indonesia comprises various types, constructions, operating methods, and parts designed to the catch target (Nurulludin et al., 2016;
Tirtadanu et al., 2018; Wijayanto et al., 2019). In marine prawn and shrimp fisheries, a mini bottom trawl gear is usually used to catch small prawn and shrimp in shallow waters, while banana prawn (Penaeus merguiensis) is caught using trammel nets (Jamal, 2015; Nurdin and Kembaren, 2015; Tirtadanu and Ernawati, 2016; Tirtadanu et al., 2017; Tirtadanu and Panggabean, 2018; Tirtadanu and Chodrijah, 2020). Based on the Regulation of the Minister of Maritime Affairs and Fisheries Number 59 of 2020 concerning Fishing Paths and Placement of Fishing Equipment as well as Fishing Aids in WPPNRI, a trammel nets is a static and passive fishing tool (API), operated using a mesh with a size above 1.5 inches, and a $P$ ris rope below $500 \mathrm{~m}$.

Fish stock density is a significant indication of fishery potential in an area, and several studies related to the stock density of prawn and shrimp resources in WPPNRI have been reported, including the report by Hargiyatno et al., (2015), where the stock of banana prawn or jerbung prawn (Penaeus merguiensis) in the Arafura Sea were estimated. In addition, a study by Tirtadanu and Ernawati (2016) identified the biomass and stock density of Penaeid shrimp resources in the Java Sea which consists of 6 genera comprising 16 species, with southern velvet shrimp (Metapenaeopsis palmensis) as the most dominant. The study also discovered other commercial species such as greasyback shrimp (Metapenaeus ensis), green tiger prawn (Penaeus semisulcatus), and banana prawn (Penaeus merguiensis). The average prawn and shrimp stock density, catch rate, and biomass in the Java Sea are estimated at $21.34 \pm 16.81 \mathrm{~kg} / \mathrm{km}^{2}, 1 \pm 0.5 \mathrm{~kg} /$ hour, and 9,938 tons, respectively. A study by Tirtadanu et al., (2018) showed the average prawn and shrimp catch rate in the eastern waters of Kalimantan with trawlers was $0.83 \mathrm{~kg} / \mathrm{hour}$, with the highest catches found at depths below $40 \mathrm{~m}$, and obtained an average prawn and shrimp stock density of $16.5 \mathrm{~kg} / \mathrm{km}^{2}$ based on calculations.

The high utilization of resources cause degradation and impairment in the development of fishery stocks (Saputra et al., 2013; Ma'mun et al., 2018). Inadequate monitoring, 
controlling and survailnace are possible factors responsible for the high utilization of these resources (Umamah et al., 2017; Akoit and Mardit, 2018; Suruan et al., 2020). This study, therefore, aims to describe the characteristics of mini bottom trawl fishing gear as well as the fishing season, and estimate the stock density as well as sustainable potential of banana prawn in Rembang Regency, using the swept area method. The findings from this study are expected to serve as a basis for efficient, sustainable, and sustainable management of this species.

\section{METHOD}

This study was conducted from September to October 2020, in the Northern Waters of Rembang Regency, with an area of $1409.7 \mathrm{~km}^{2}$ (Figure 1), using both primary and secondary data. Primary data was collected directly from observations, measurements, and interviews with fishermen, while secondary data, including data on the number and types of fishing gear, as well as production and production values, was obtained through a literature review.

Sampling was performed using the simple random method, and this required 5 fishing trips at 5 different bases with 11 fishing operation points carried out from September to October 2020. This sampling method assumes the samples taken are homogeneous or have the same characteristics, therefore, each individual has the opportunity to be sampled. In this study, banana prawn was the selected sample, based on the species' status as a catch with economic value and the dominance within the northern waters of Rembang Regency.

Subsequently, data analysis was carried out using 4 methods, the analysis of the mini bottom trawl fishing gear ratio to determine the mini bottom trawl fishing gear's characteristics, and the analysis of the fishing season index (IMP) to determine the fishing season for banana prawn, as well as the swept area analysis to determine stock density and surplus production model for estimating maximum sustainable yield (MSY) of banana prawn.

The analysis of fishing gear was based on SNI 01-7233-2006 "Standard Forms of Trawl Construction" to determine the ratio between the length of the trawl's parts and the total trawl length. Furthermore, the fishing season patterns or Fishing Season Index (IMP $\%$ ) were analyzed using the moving average method, based on the steps by Dajan (1983) and the formula developed by Wiyono (2001), as in the following equation.

(1) Calculate the monthly CPUE series over 5 years.

$\mathrm{Ni}=$ CPUEi

Where:

i : indicates the $1,2,3, \ldots$ and

$\mathrm{Ni} \quad$ : represents order I.

(2) Compile a series of monthly CPUE values for 12 months.

$N p=\sum_{j=p-6}^{p+6} C P U E$

Where:

p : connotes $7,8, \ldots, n-5$,

$\mathrm{Np} \quad$ : depicts the $\mathrm{p}$-the order

$\mathrm{J} \quad$ : signifies the jth order in the series $\mathrm{Ni}$.

(3) Compile a series of 2 months for each month.

$N r=\frac{1}{24} \sum_{m=r-6}$ CPUEk

Where:

$r \quad$ : represents $7,8, \ldots, \mathrm{n}-5$,

$\mathrm{Nr}$ : indicates the r-the order

$\mathrm{m}$ : connotes the mth order in the Nq series.

(4) Calculate the average ratio for each month.

Average ratio $=\frac{\text { CPUE }}{\text { Rata-rata } 2 \text { bulanan }}$

(5) Compile the monthly average ratio value and calculate the average or seasonal variation, as well as the fishing season index, using the equations below.

The average ratio for jth month $=\frac{1}{4} \sum_{i=1}^{4} X i j$

Total average ratio $=\frac{1}{4} \sum_{j=1}^{12} \sum_{i=1}^{4} X_{i j}$

Correction factor $(\mathrm{FK})=\frac{1200}{\text { Jumlah rasio rata-rata }} \ldots$

$(\mathrm{IMP} \%)=$ Average ratio for jth month $\mathrm{x}$ correction factor

The potential analysis includes the stock density value, MSY, and utilization rate. The stock density value is obtained using the swept area calculation method, based on the swept area traversed (Sparre and Venema, 1998; 
Pezzuto et al., 2008), while the area covered by each trawling in each sweep was calculated using the following equation.

$\mathrm{a}=\mathrm{S} . \mathrm{DF}$

Where:

$\mathrm{S}: \mathrm{v} . \mathrm{t}$

a : represents area of the swept area (mile ${ }^{2}$ or $\mathrm{km}^{2}$ )

$S$ : the length or sweep distance (miles or $\mathrm{km})$

DF: opening width of nets (m)

$\checkmark \quad$ : the speed of the ship during towing in knots (1 knot = nautical miles/hour)

$\mathrm{t} \quad$ : the time of towing (hour)

$\mathrm{a}=\mathrm{C} \times \mathrm{HR} \times \mathrm{V} \times \mathrm{H}$

Where:

a : represents the area swept

$C$ : the constant width of the net's mouth at the time of operation (0.5)

$\mathrm{HR}$ : head rope length

$\mathrm{V}$ : the speed of the boat when towing

$\mathrm{T}$ : the towing duration

The stock density was calculated using the formula below (Sparre and Venema, 1998).

$Q=C w / a \times$ ef

Where:

Q : indicates the density of demersal fish per sweep area $\left(\mathrm{kg} / \mathrm{km}^{2}\right)$

Cw : fish catch per area sweep $(\mathrm{kg})$

a : the area of the swept area surveyed $\left(\mathrm{km}^{2}\right)$

ef $\quad$ denotes the constant 0.4

Meanwhile, the opening of the otter board and the net's mouth, as well as the rope's length were calculated using the formula by Prado and Dreimere (1990).

$D=(B A) . F+A D=2 \sin d F+A$

Where:

D : represents the approximate opening of the otter board $(\mathrm{m})$

A : indicates the width formed by the sheet rope inside $(\mathrm{m})$

B : signifies the width formed by the sheet rope outside $(\mathrm{m})$

$\mathrm{F}$ : connotes the slambar rope length from inside width to otter board $(\mathrm{m})$

Furthermore, the Schaefer model was used to calculate the MSY and optimum effort of banana prawn. The optimum effort and MSY are obtained using the formula below. Also, the relationship between effort and catch produces a symmetrical parabolic curve (Sparre and Venema, 1998; Sibagariang et al., 2011; Simbolon et al., 2011).

fmsy $=\frac{-a \cdot}{2 b}$

$M S Y=\frac{a^{2}}{4 b}$

The total allowable catch was calculated using the formula below.

$\mathrm{TAC}=\mathrm{MSY} \times 80 \%$

Meanwhile, the percentage utilization rate was calculated using the formula below.

$\mathrm{TP}=\mathrm{x} 100 \% \frac{\mathrm{y}}{\mathrm{MSY}}$

Where:

y : represents the catch

$f$ : fishing effort

a : the intercept

b : the slope

TAC : indicates the total allowable catch

MSY : the maximum sustainable catch.

\section{RESULT}

The coastal area of Rembang Regency is located on the regency's northern coast and cuts into 6 sub-districts; Kaliori, Rembang, Lasem, Sluke, Kragan, as well as Sarang, each with has at least one Fish Auction Place (TPI), except for Lasem sub-district. Rembang Regency has 10 TPIs, including TPI Tunggulsari, Tanjungsari, Tasik Agung I, Tasuk Agung II, Banggi Market, Pangkalan, Views, Karanglincak, Karanganyar, and Sarang. Of these TPIs, there are 1 in Kaliori District (Tunggulsari Village), 4 in Rembang District (1 in Tanjungsari Village, 2 in Tasik Agung Village, and 1 in Pasar Banggi Village), 1 in Sluke District (Pangkalan Village), 3 in Kragan District, (1 in the Village Views, 1 in Karanglincak Village, and 1 in Karanganyar Village), and 1 in Sarang District (Karangmangu Village). In addition to these, there is also 1 PPP in Rembang District (Tasik Agung Village), 2 PPIs in Kragan District (Karanganyar Village) and Sarang District (Karangmangu Village). Figure 2 shows the capture fisheries production in Rembang Regency has a fairly large value. 


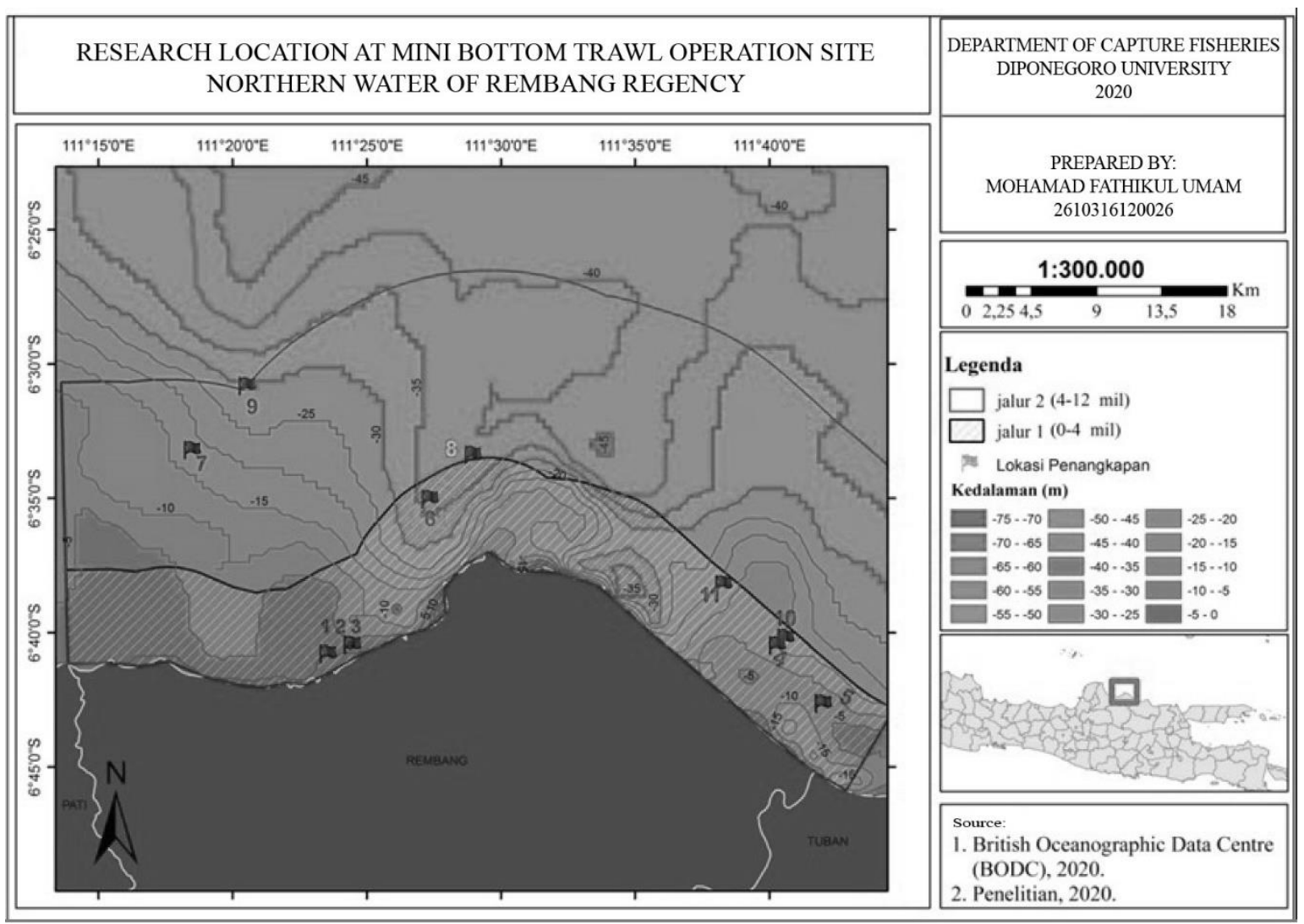

Figure 1 A map of the study area in the Northern Waters of Rembang Regency. Source: Research, 2020.

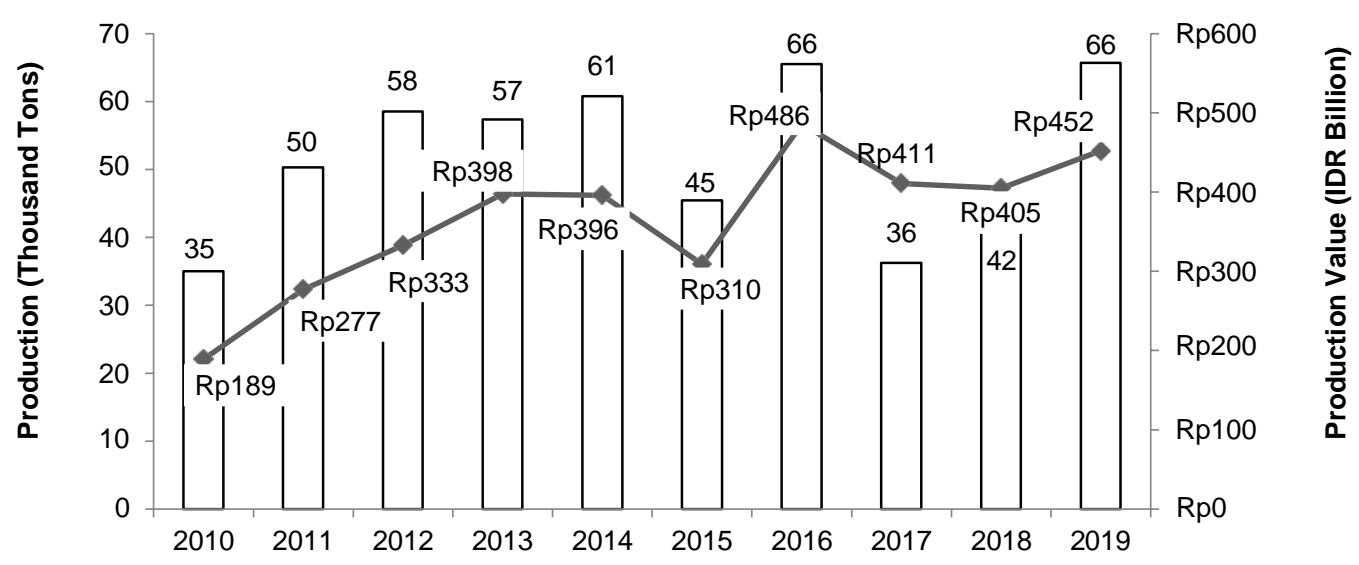

Figure 2 Capture Fisheries production in Rembang Regency from 2010 - 2019.

The production of capture fisheries in Rembang Regency fluctuated, and tended to increase steadily from 2010 to 2012 , but decreased slightly in 2013 from $58,496,891 \mathrm{~kg}$ to $57,369,913 \mathrm{~kg}$ (Figure 2). However, from 2014-2019 the value tended to fluctuate with a significant decrease and increase in 20162017 and 2018-2019, respectively. The banana prawn production increased steadily from 2010 to 2014, but decreased significantly, from 2014 to 2019 (Figure 3). However, the values for 2017 and 2019 were not recorded because the values were infinitesimal. The decrease in production due to natural factors or the surrounding aquatic environment, as well as the unpredictable seasonal or weather factors tend to affect the fishing season for banana prawn.

Figure 4 shows the production and price of banana prawn, valued at IDR. 40.000,00 - 
IDR. 150,000.00, depending on the size per kilogram. According to the fishermen at Rembang Regency, Banana prawn (Penaeus merguiensis) with 40-50 or $>50$ individuals per kilogram is valued at IDR. 40,000, while the counterparts of $30-40,20-30$, and $<20$ are valued at IDR. 90,000, 120,000.00, and IDR $150,000.00$, respectively. However, with very low production in 2017 and 2019, the production value fell to IDR. 0 .

In Rembang Regency, prawn and shrimp catching are performed using 2 types of fishing gear, these are sotok or mini bottom trawls and trammel nets. The mini bottom trawl is usually used to catch small prawn and shrimp, while trammel nets is for certain species, including banana prawn (Penaeus merguiensis) and giant tiger prawn (Penaeus monodon). Figure 5 shows a graph of the number of trammel net fishing gear used in Rembang Regency. A total of 4 mini bottom trawl nets were used in this study, each with a total length of $15.77 \mathrm{~m}, 16.5 \mathrm{~m}, 20.44 \mathrm{~m}$, and $25.2 \mathrm{~m}$. Table 1 and Figure 6 show detailed construction of mini bottom trawl or sotok nets. Table 2 shows the ratio of the mini bottom trawl net's standard form differs in each part of the construction and refers to the $\mathrm{SNI}$ for the standard form of trawl nets. Based on Figure 5, the number of trammel net fishing gear was relatively stable over the years, albeit with slight fluctuation in 2014, where the number of trammel nets decreased significantly from 1977 to 1583 fishing gear units.

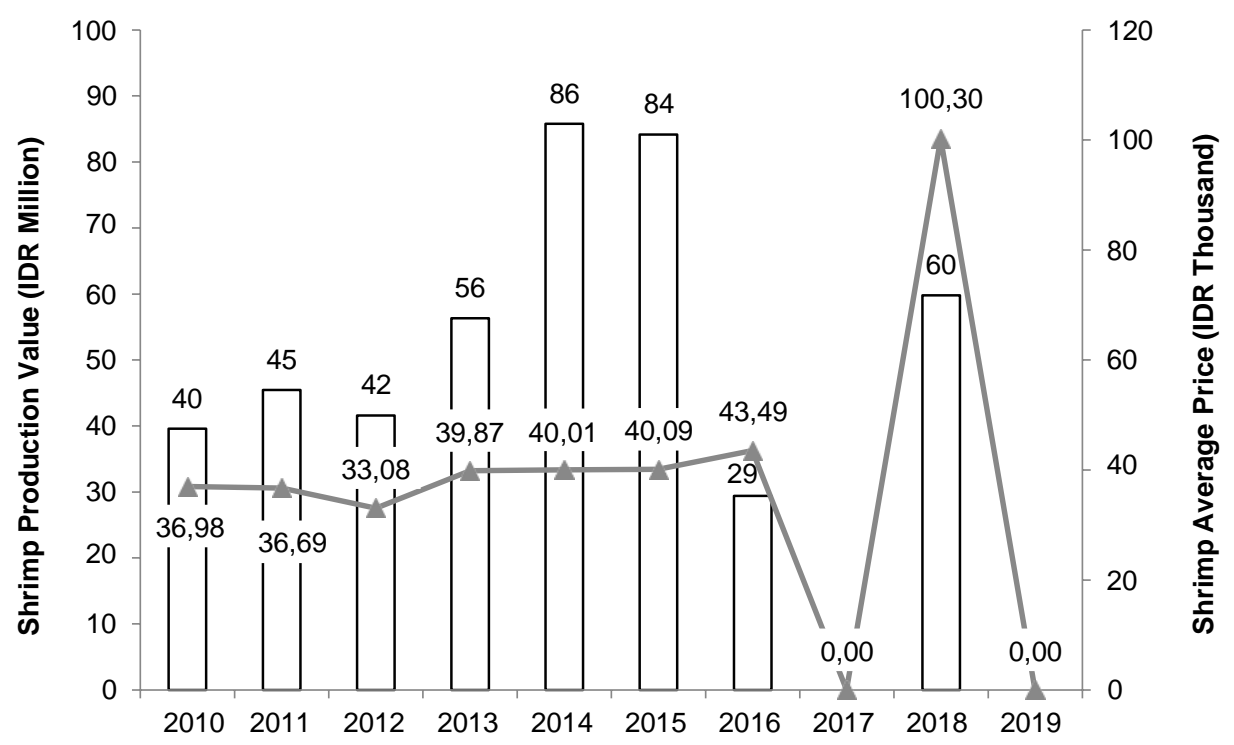

Figure 4 The banana prawn production in Rembang Regency in 2010 - 2019.

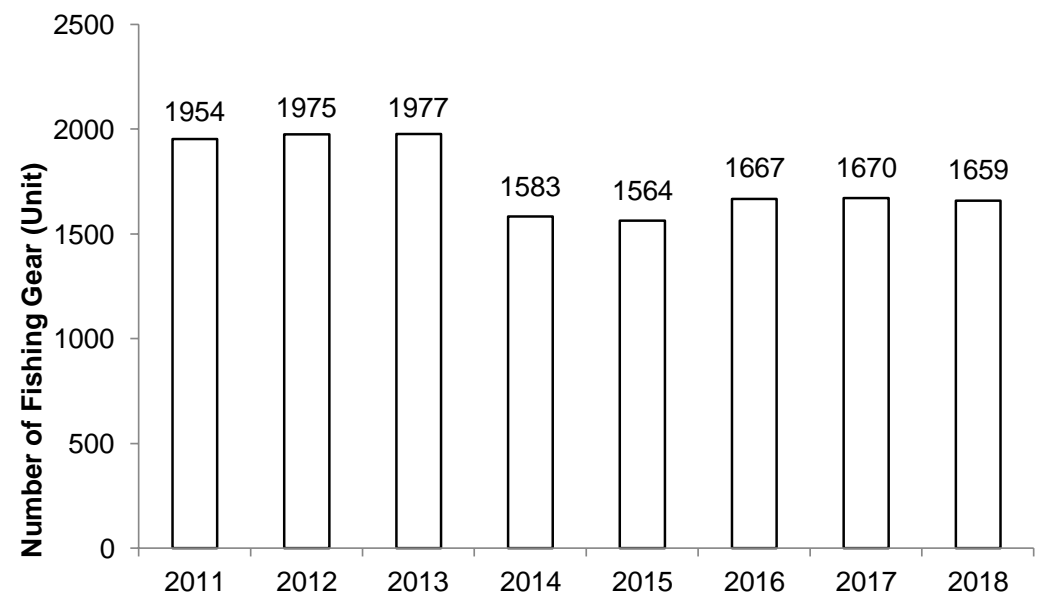

Figure 5 The number of Trammel net in Rembang Regency from 2010 - 2019. 


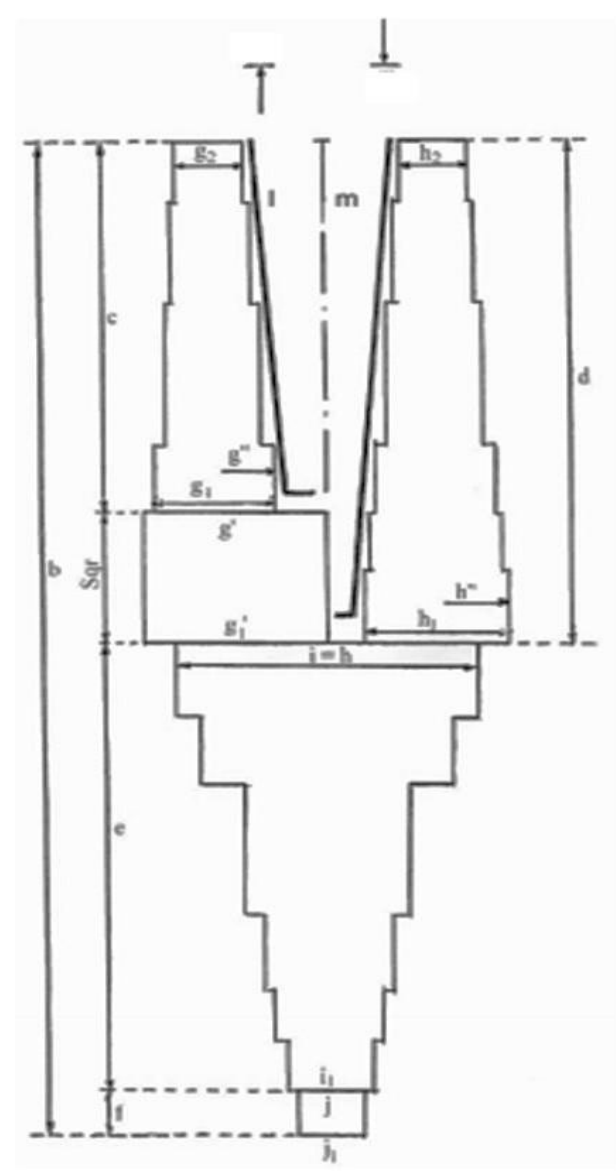

Figure 6 The design and Construction of mini bottom trawl nets (Source: Research (2020) ; Badan Standarisasi Nasional (2006)

Caption:

1) Length of sections of the longitudinal cut net:
a) The length of the top rope
$:$ I
b) The length of the bottom ris strap : $m$
c) Length of the net's mouth
$: a$
d) Total length of the net
$: \mathrm{b}$
e) Length of upper wing
f) The length of the lower wing
$: c$
g) Length of square section
$: \mathrm{d}$
h) Length of the net's body
$:(\mathrm{dc})$
i) Length of mesh bag section
$: e$
$: f$

2) The length of the cross-sectional sections of the net:
a) Circumference of net opening
: a
b) Half of the net opening's circumference : $h$
c) Width of the upper wing's front end : :g2
d) Width of the rear tip of upper wing : :g1
e) Width of the lower wing's forewings : :h2
f) Width of the lower wing's hind wings : $:$ 1
g) Width of the front end square $: g^{\prime}$
h) Width of the back end square $: g$
i) Width of the body's front end
j) Width of the body's rear end
k) Width of the pouch's front end
l) Width of pouch's back end 
Table 1 The mini bottom traw/ Net Construction Sizes

\begin{tabular}{clcccc}
\hline \multirow{2}{*}{ No Part Name } & \multicolumn{4}{c}{ Net Size (m) } \\
\cline { 3 - 6 } & & $\mathbf{1}$ & $\mathbf{2}$ & $\mathbf{3}$ & $\mathbf{4}$ \\
\hline 1 & Width of the front end of the body & 3.4 & 3.8 & 4.6 & 5.2 \\
2 & Width of front end square & 3.05 & 3.25 & 4.25 & 4.85 \\
3 & Width of upper wing's rear tip & 2.95 & 3.1 & 4 & 3.87 \\
4 & Width of the upper wing's tip & 1.43 & 1.62 & 1.65 & 1.67 \\
5 & The width of the lower wing's hind wing & 3.25 & 3.6 & 4.38 & 4.3 \\
6 & Width of the lower wing's front end & 1.43 & 1.62 & 1.65 & 1.67 \\
7 & Width of the back end of the body & 0.8 & 0.88 & 0.95 & 0.9 \\
8 & The width of the pocket's front end & 0.75 & 0.85 & 0.9 & 0.85 \\
9 & The width of the pocket's back & 0.75 & 0.85 & 0.9 & 0.85 \\
10 & Top strap length & 11.9 & 13.8 & 19.2 & 20.8 \\
11 & Bottom strap length & 16.37 & 18.3 & 22.4 & 25.2 \\
12 & Upper wing length & 5.76 & 6.9 & 9.2 & 9.8 \\
13 & Lower wing length & 7.44 & 9 & 10.4 & 12.2 \\
14 & Length of square section & 1.92 & 2.34 & 1.54 & 2.32 \\
15 & The length of the net's body & 6.52 & 4.25 & 6.82 & 4.65 \\
16 & Mesh bag section length & 1.25 & 3.15 & 1.68 & 3.2 \\
17 & Total length of the net & 15.77 & 16.5 & 19 & 25.2 \\
18 & Around the net's mouth & 6.8 & 7.6 & 9.2 & 9 \\
19 & Sheet Length (m) & 27.2 & 80 & 40 & 40 \\
20 & Sample Rope Length (m) & 1 & 1 & 1 & 1 \\
21 & Distance Between Branches (cm) & 17 & 25 & 23 & 24 \\
22 & Distance Between Sample Branch Lines (cm) & 48 & 60 & 57 & 49 \\
23 & Sweep rope length(m) & 3 & 14.4 & 9.6 & 0.5 \\
24 & Buoy (seed) & 30 & 30 & 28 & 25 \\
25 & Weight (kg) & 5 & 6 & 7 & 10 \\
26 & Float material & PVC & PVC & PVC & PVC \\
27 & Ballast material & Lead & Lead & Lead & Lead \\
\hline
\end{tabular}

Source: Research, 2020.

Table 2 Calculation of the Ratio Value of the Standard Form of Mini Bottom Trawl Nets

\begin{tabular}{ccccccc}
\hline \multirow{2}{*}{ No } & \multirow{2}{*}{ Calculation Formula } & \multicolumn{5}{c}{ Ratio Value } \\
\cline { 3 - 6 } & & SNI & 1 net & 2 net & 3 net & $\mathbf{4 . n e t}$ \\
\hline 1 & $\mathrm{i} / \mathrm{h}$ & 1,000 & 1,000 & 1,000 & 1,000 & 1,000 \\
2 & $\mathrm{~g} /=\mathrm{g} / \mathrm{h}$ & $0.585-0.715$ & 0.897 & 0855 & 0.924 & 0.933 \\
3 & $\mathrm{~g} 1 / \mathrm{h}$ & $0.420-0.520$ & 0.868 & 0.816 & 0.870 & 0.744 \\
4 & $\mathrm{~g} 2 / \mathrm{h}$ & $0.240-0.305$ & 0.421 & 0.426 & 0.359 & 0.321 \\
5 & $\mathrm{~h} 1 / \mathrm{h}$ & $0.505-0.620$ & 0.956 & 0.947 & 0.952 & 0.827 \\
6 & $\mathrm{~h} 2 / \mathrm{h}$ & $0.245-0.305$ & 0.421 & 0.426 & 0.359 & 0.321 \\
7 & $\mathrm{i} 1 / \mathrm{h}$ & $0.470-0.580$ & 0.235 & 0.232 & 0.207 & 0.173 \\
8 & $\mathrm{j} / \mathrm{h}$ & $0.210-0.265$ & 0.221 & 0.224 & 0.196 & 0.163 \\
9 & $\mathrm{j} 1 / \mathrm{h}$ & $0.210-0.266$ & 0.221 & 0.224 & 0.196 & 0.163 \\
10 & $\mathrm{l} / \mathrm{b}$ & $0.725-0.895$ & 0.755 & 0.836 & 0.939 & 0.825 \\
11 & $\mathrm{~m} / \mathrm{b}$ & $0.965-1.190$ & 1.038 & 1.109 & 1.096 & 1,000 \\
12 & $\mathrm{c} / \mathrm{b}$ & $0.340-0.420$ & 0.365 & 0.418 & 0.450 & 0.389 \\
13 & $\mathrm{~d} / \mathrm{b}$ & $0.470-0.580$ & 0.472 & 0.545 & 0.509 & 0.484 \\
14 & $\mathrm{sqr} / \mathrm{b}$ & $0.130-0.165$ & 0.122 & 0.142 & 0.075 & 0.092 \\
15 & $\mathrm{e} / \mathrm{b}$ & $0.395-0.490$ & 0.413 & 0.258 & 0.334 & 0.185 \\
16 & $\mathrm{f} / \mathrm{b}$ & $0.040-0.055$ & 0.079 & 0.191 & 0.082 & 0.127 \\
17 & $\mathrm{l} / \mathrm{m}$ & $0.675-0.830$ & 0.727 & 0.754 & 0.857 & 0.825 \\
18 & $\mathrm{a} / \mathrm{b}$ & $0.995-1.220$ & 0.431 & 0.461 & 0.450 & 0.357 \\
\hline
\end{tabular}

Source: Research, 2020.

An analysis of the potential resources of banana prawn (Penaeus merguiensis), including the stock density was calculated using the swept area method, an approach used to determine the total density of fish resource stocks in any given area of water (Table 3).
There are 2 fishing seasons for banana prawn in Rembang Regency. The west season usually occurring in the rainy season, between January and March. Then, the east season usually occurring in the dry season, between June and August (Figure 7).

Based on Table 3, the total stock density of banana prawn in the Northern 
Waters of Rembang Regency is $13.07 \mathrm{~kg} / \mathrm{km}^{2}$, with biomass of $1,654.98$ tons. This is very low, compared to the annual total production, where the highest value recorded in the last 10 years was $2,144 \mathrm{~kg}$ in 2014. Meanwhile, the monthly total catch of Banana prawn in the last 10 years was 2,160 kg, 1,637 kg, and 1,528 $\mathrm{kg}$, for January, February, and July, respectively. Furthermore, the lowest catches of $265 \mathrm{~kg}, 112 \mathrm{~kg}$, and $414 \mathrm{~kg}$ were recorded between October and December, respectively, the transition season from the dry to the rainy season.

In addition to banana prawn, several other species are caught using the mini bottom trawl fishing gear, including speckled shrimp or Kasap or Dogol or Flames (Metapenaeus monoceros), southern velvet shrimp
(Metapenaeopsis palmensis), and giant tiger prawn (Penaeus monodon). Based on the total catch from mini bottom trawl fishing gear, the banana prawn catch was much smaller, compared to speckled shrimp (Metapenaeus monoceros) and southern velvet shrimp (Metapenaeopsis palmensis) counterparts. Table 5 shows the details of the catch obtained using sotok gear.

According to Table 5, the total catch was dominated by speckled shrimp (Metapenaeus monoceros). The highest catch was obtained on the 4th fishing trip, with a total catch of Banana prawn (Penaeus merguiensis), speckled shrimp (Metapenaeus monoceros), and southern velvet shrimp (Metapenaeopsis palmensis) of $0.924,12$, and $3.5 \mathrm{~kg}$, respectively.

Table 3 The results of the swept area

\begin{tabular}{llc}
\hline No. & \multicolumn{1}{c}{ Calculation } & Results \\
\hline 1. & Sweeping Area of Catch & $0.4768 \mathrm{~km}^{2}$ \\
2. & Area of Research Waters & $1,409.7 \mathrm{~km}^{2}$ \\
3. & Percentage of Research Area Sample & $0.034 \%$ \\
4. & Total Catch Banana prawn (Penaeus merguiensis) & $3.116 \mathrm{~kg}$ \\
\hline
\end{tabular}

Source: Research, 2020.

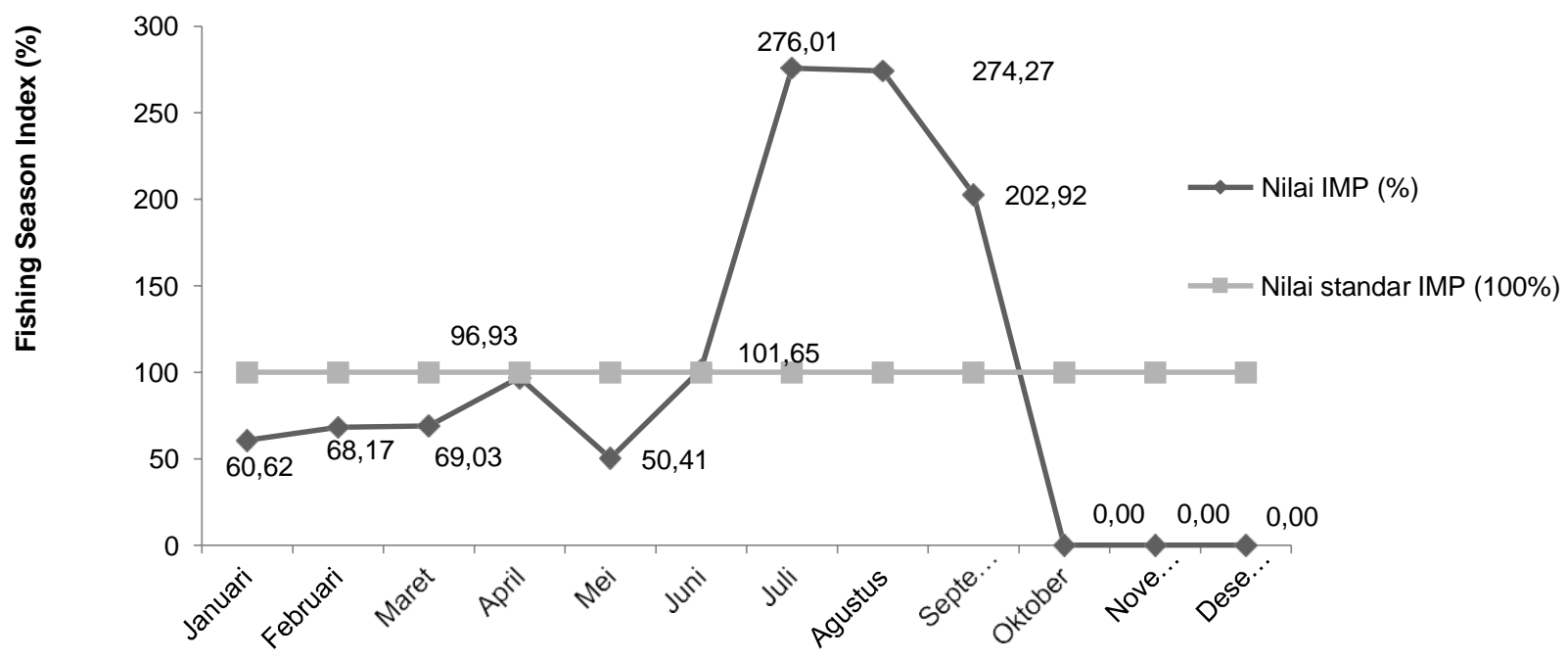

Figure 7 The seasonal Index of Banana prawn Catch in Rembang Regency from 2012 - 2016

Table 4 The Stock Density.

\begin{tabular}{cccccc}
\hline Trip & Point & Catch $(\mathrm{kg})$ & Swept Area $\left(\mathrm{km}^{2}\right)$ & Depth $(\mathrm{m})$ & Stock Density $\left(\mathrm{kg} / \mathrm{km}^{2}\right)$ \\
\hline 1 & $1,2,3$ & 0.722 & 0.0351 & $0-5$ & 41.14 \\
2 & 4.5 & 0.924 & 0.1434 & $5-10$ & 12.89 \\
3 & 6.7 & 0.357 & 0.0955 & $15-35$ & 7.48 \\
4 & 8.9 & 0.94 & 0.1237 & $30-40$ & 15.20 \\
5 & 10,11 & 0.173 & 0.0791 & $10-20$ & 4.37 \\
\hline \multicolumn{7}{c}{ Average } \\
\hline
\end{tabular}

Source: Research, 2020. 
Table 5 Types of Captured Prawn and Shrimp Stock

\begin{tabular}{|c|c|c|}
\hline Trip & Types of Shrimp Catch & Quantity (g) \\
\hline \multirow[t]{4}{*}{1} & Banana prawn (Penaeus merguiensis) & 722 \\
\hline & Giant tiger prawn (Penaeus monodon) & 295 \\
\hline & Southern velvet shrimp (Metapenaeopsis palmensis) & 179 \\
\hline & Speckled shrimp (Metapenaeus monoceros) & 197 \\
\hline \multirow[t]{3}{*}{2} & Banana prawn (Penaeus merguiensis) & 940 \\
\hline & Speckled shrimp (Metapenaeus monoceros) & 2683 \\
\hline & Southern velvet Shrimp (Metapenaeopsis palmensis) & 473 \\
\hline \multirow[t]{3}{*}{3} & Banana prawn (Penaeus merguiensis) & 357 \\
\hline & Speckled shrimp (Metapenaeus monoceros) & 10000 \\
\hline & Southern velvet Shrimp (Metapenaeopsis palmensis) & 2371 \\
\hline \multirow[t]{3}{*}{4} & Banana prawn (Penaeus merguiensis) & 924 \\
\hline & Speckled shrimp (Metapenaeus monoceros) & 12000 \\
\hline & Southern velvet Shrimp (Metapenaeopsis palmensis) & 3500 \\
\hline \multirow[t]{3}{*}{5} & Banana prawn (Penaeus merguiensis) & 173 \\
\hline & Giant tiger prawn (Penaeus monodon) & 103 \\
\hline & Speckled shrimp (Metapenaeus monoceros) & 163 \\
\hline
\end{tabular}

Source: Research, 2020

\section{Production Surplus Analysis}

The analysis of surplus production is a model created to regulate the allowable fishing effort to capture fish resources without exceeding the maximum sustainable yield (MSY) (Sparre and Venema, 1998). This analysis was carried out using the schafer model, where the CPUE (Catch Per Unit Effort) value is the result of the comparison between the catch value and the effort. The CPUE value was obtained from production data and fishing trips for banana prawn using a trammel net from 2010 to 2018 , therefore the fishing gear do not need to be standardized (Figure 8).

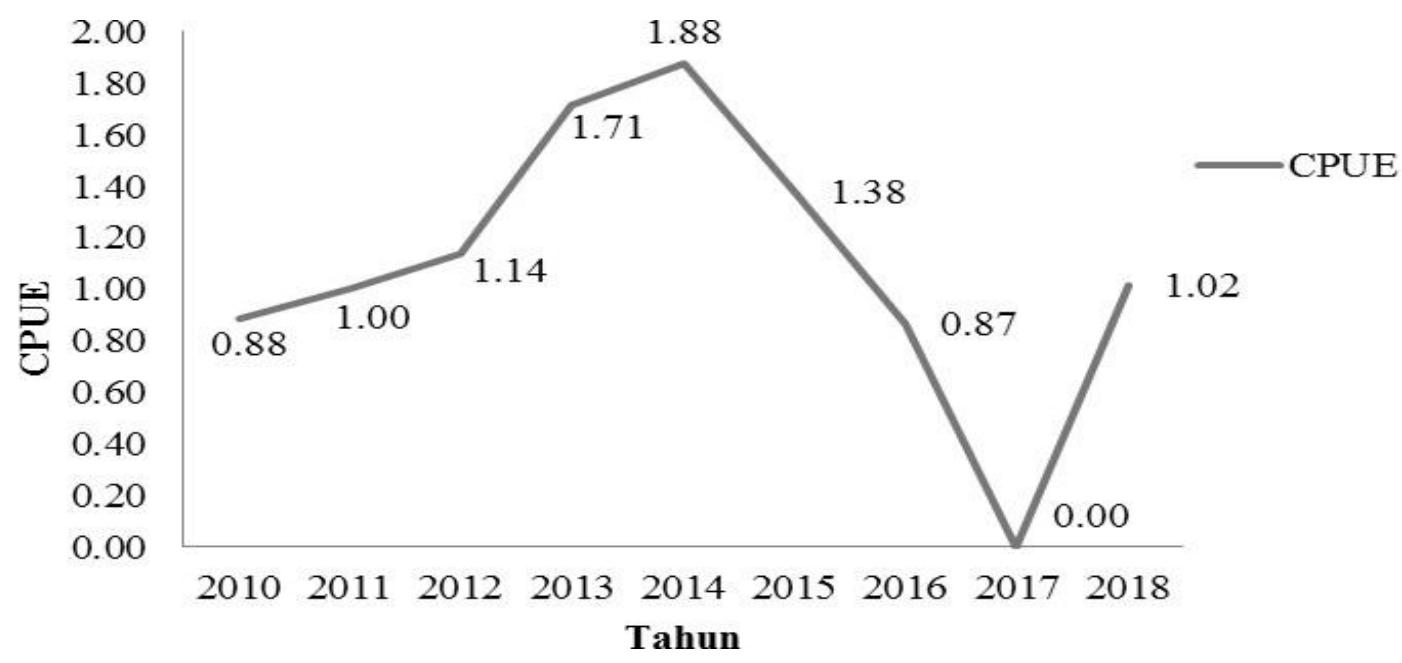

Figure 8 The CPUE of Banana prawn in Rembang Regency from 2010 - 2018 


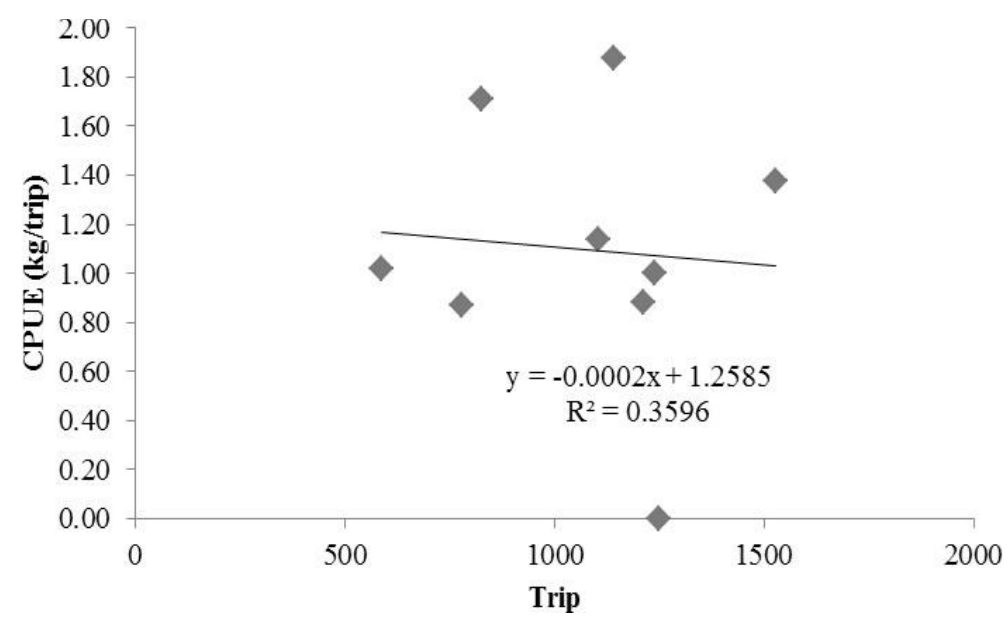

Figure 9 The relationship between CPUE and the fishing trips ( $R$ Square Value) of banana prawn in Rembang Regency from 2010 - 2018

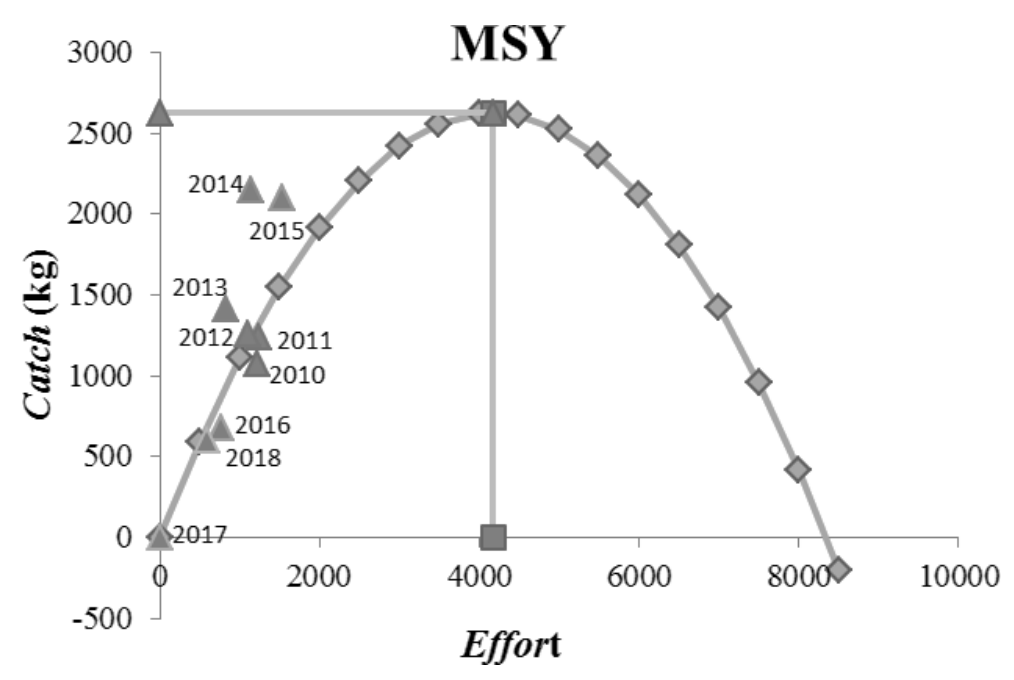

Figure 10 The MSY (Maximum Sustainable Yield) of banana prawn in Rembang Regency

Table 6 The utilization rate of banana prawn

\begin{tabular}{cccc}
\hline Year & C $(\mathrm{kg})$ & CMSY $(\mathrm{kg})$ & TP $(\%)$ \\
\hline 2010 & 1070 & 2625 & $41 \%$ \\
2011 & 1238 & 2625 & $47 \%$ \\
2012 & 1257 & 2625 & $48 \%$ \\
2013 & 1412 & 2625 & $54 \%$ \\
2014 & 2144 & 2625 & $82 \%$ \\
2015 & 2100 & 2625 & $80 \%$ \\
2016 & 676 & 2625 & $26 \%$ \\
2017 & 0 & 2625 & $0 \%$ \\
2018 & 596 & 2625 & $23 \%$ \\
\hline \multicolumn{4}{c}{} \\
\hline
\end{tabular}

\section{DISCUSSION}

Data analysis using the swept area method was performed to obtain information on the condition of banana prawn fishery in the Northern Waters of Rembang Regency, for instance, the fishing grounds, seasons, and gear used, as well as the potential resources. 


\section{The Condition of Banana prawn (Penaeus merguiensis) Fishery in Rembang Regency}

The drastic decline in 2017 and 2019 of banana prawn production was occurred due to natural factors, the surrounding aquatic environment, and unpredictable seasonal or weather factors. According to Ma'mun et al., (2018), the fluctuation and trend of reduction in the sustainable potential of demersal fish within WPPNRI 712, from 2011-2015, recorded an average annual decline of $12.1 \%$ due to fishing pressure, indicating conditions of overfishing and resource degradation. In addition, Mustaruddin et al., (2016) stated these production fluctuations are often triggered by salinity, temperature, offshore current (coastal currents), swells, and local winds in fishing grounds. To limit the conditions of overfishing and resource degradation, fishery management need to be implemented through a fisheries management plan. The main objective of the fisheries management plan is to sustain fishery resources by considering stock, environment, social and economic factors. If the stock can recover, it can result higher catch rates and then decrease the cost per unit catch (Hart and Reynolds, 2002; Grimm et al., 2012).

Banana prawn is the most expensive prawn, and is, therefore, a major target for fishermen in Rembang Regency. According to Manadiyanto et al., (2017a; b), the price per kilogram of banana prawn in Pati was IDR. $80.000,00$ - IDR. 100,000.00, while the species marketed in Tuban are speckled shrimp and banana prawn. Furthermore, there are several classifications of prawn size determined by the supplier based on the exporter's specifications of Supersize I (15-24 individu per kilo gram), size II (25-30 individu per kilo gram), size III (31-40 individu per kilo gram), and size IV (41-50 individu per kilo gram). At the time of the study and the supplier level, the price of pranw per $\mathrm{kg}$ was, size I IDR.180.000,- size II IDR.160,000,- size III 120,000 ,- and size IV IDR.100.000,-. The size at the supplier level refers to the Japanese size classification (Japan size standard for first-class prawn).

\section{Characteristics of Banana prawn (Penaeus merguiensis) Fishery in Rembang Regency}

In Rembang Regency, prawn and shrimp are caught using 2 types of fishing gear: sotok or mini bottom trawls, and trammel nets. Sotok nets or mini bottom trawl is used irrespective of season, while trammel nets are only used during the prawn and shrimp season (Kartikaningtyas et al., 2018; Dewanti et al., 2019; Ihsan and Tajuddin, 2019). According to the results, most of the mini bottom trawl used have a ratio value outside the existing SNI value, determined through a comparison between the widths of the net sections. Table 1 shows only the comparison value of net width ( $j$ and $j 1$ ) for nets 1 and 2 which follows the SNI. Furthermore, the net length counterparts mostly follow the SNI value, and all have a value between 0.995 as well as 1220.

Based on Table 2, the nets used by fishermen in Rembang tend to be smaller, compared to the SNI, indicating the nets are narrower, compared to the standard value. Sasmita et al., (2013) as well as Ambarwati and Adi (2019), showed fishermen's cantrang nets have a smaller forewing-net width $(\mathrm{g} 2 / \mathrm{h})$ ratio and wider wingtips to increase the catch probability, while the lower body has a narrow width to prevent fish from leaving the net after getting caught.

In Rembang Regency, banana prawn is mostly caught during certain seasons. Figure 6 shows the highest total IMP of $276.01 \%$ was recorded in July, while the least values of $0 \%$ were recorded from October to December. Furthermore, PMI values above $100 \%$ were recorded from June to September, indicating this is the species' peak season, while values between $50 \%$ and $70 \%$ were recorded from January to May. This is reinforced by Subagio (2019), stating the peak prawn and shrimp season in the waters of Surabaya City lasts for 6 months: January, April, May, June, November, and December.

In addition, the highest IMP value during the peak season was recorded in May $(380.85 \%)$, followed by June (166.16\%), April (140.03\%), December (138.27\%), and January (107.20\%). A study by Mosha and Gallardo, (2013) also reported similar findings in the temporal distribution of $P$. monodon and $P$. indicus in Saadan, a Tanzanian estuary area, observed between January and February (dry season) and March and April (rainy season). This was confirmed in the report by Amron et al., (2009), stating the banana prawn fishing season occurs throughout the year, and peaks during the dry season (April - September). Similarly, Tirtadanu and Chodrijah (2020) showed the highest speckled shrimp and banana prawn catch from Cilacap waters using trammel nets, 
were obtained in March and August, respectively.

Meanwhile, Ihsan and Tajuddin (2019) showed the peak prawn and shrimp fishing season in the waters of Pangkep Regency, occurred in January, February, March, and April, indicating several factors influence the species' peak season in waters of the Republic of Indonesia.

\section{Swept Area}

The highest stock density was recorded on trip 1, with a swept area, depth, and stock density of $0.0351 \mathrm{~km}^{2}, 0-5 \mathrm{~m}$, and 41.14 $\mathrm{kg} / \mathrm{km}^{2}$, respectively (Table 4 ). Meanwhile, the mini- mum density was obtained on trip 5, with a swept area, depth, and stock density of $0.0791 \mathrm{~km}^{2}, 10-20 \mathrm{~m}$, and 4.37 $\mathrm{kg} / \mathrm{km}^{2}$, respectively (Table 4 ). In addition, the average stock density value from all fishing locations was $16.22 \mathrm{~kg} / \mathrm{km}^{2}$. Fish stock density is an indication of fishery potential in a region. The difference in stock density values may be due to differences in research time or differences in seasons (Sumiono et al., 2011). According to Nuruliuddin et al., (2016); and Tirtadanu et al., (2018) the average prawn density in East Kalimantan and the Java sea are $16.5 \mathrm{~kg} / \mathrm{km}^{2}$ and $21.34 \pm 16.81 \mathrm{~kg} / \mathrm{km}^{2}$, respectively, while the average prawn catch rate in the West Sumatran waters is $2.3 \mathrm{~kg} / \mathrm{hour}$ with a stock density of 0.053 tons $/ \mathrm{km}^{2}$.

In this study, the prawn and shrimp catches were dominated by speckled shrimp (Metapenaeus monoceros), while the highest total catch was obtained on the 4th fishing trip, with a total catch of $0.924 \mathrm{Kg}, 12 \mathrm{Kg}$, and $3.5 \mathrm{Kg}$ for banana prawn (Penaeus merguiensis), speckled shrimp (Metapenaeus monoceros) and southern velvet shrimp (Metapenaeopsis palmensis), respectively. These results were obtained from fishing operations at the highest depth compared to other fishing operations performed between 25-40 m depth. Tirtadanu et al., (2017) stated the highest vertical prawn and shrimp stock density in the Java Sea is obtained at a depth of 40 to $50 \mathrm{~m}$, presumably because most fishermen carry out intensive fishing at depths below $20 \mathrm{~m}$.

\section{Production Surplus Analysis}

Figure 8 shows the fluctuations in the CPUE value, where an increase occurred from 2010 to 2014, and the peak value of 1.88 kgh / trip occurred in 2014, while a significant reduction occurred from 2014 to 2017 , where a value of 0 was recorded. According to the head of the Rembang UPT (TPI Management Unit), the banana prawn catch in this year was infinitesimal, and, therefore, not recorded. Also, the relationship between the CPUE value and the number of trips is illustrated in the results of simple linear regression analysis, using secondary data from 2010 to 2018.

The graph of the banana prawn catch against fishing effort forms a negative linear graph, where the catch per type of effort is bound to decrease with an increase in the number of fishing trips (Figures 9 and 10). In addition, a score of $\mathrm{R}^{2}=0.3596$ implies the number of fishing trips has a $35.96 \%$ effect on the CPUE value, with the remaining influence coming from other factors, including environmental factors. The graph also shows a linear equation, $y=-0.0002 x+1.2585$, implying the slope has a value of -0.0002 , meaning the fish stock decreases by 1.0002 $\mathrm{kg}$, for every additional fishing effort. This was reinforced in the reports by Akoit and Mardit (2018) and Amir et al., (2018), where the slope had a value of 0.00005 , implying the fish stock decreases by $1.00005 \mathrm{Kg}$ for every additional fishing operation, but increases by 1.00005 $\mathrm{Kg}$, for every fishing operation is not carried out.

Based on Figure 9, the number of banana prawn catches during MSY or Cmsy conditions is $2,625 \mathrm{~kg}$, while the number of fishing efforts under MSY or Emsy conditions is 4,172 fishing trips. Knowledge of the Cmsy value enables the TAC (Total Allowable Catch) to be calculated, and this value was determined to be $2,100(\mathrm{~kg})$ or $80 \%$ of the Cmsy value obtained. This is reinforced by Umar et al., (2020), stating the Total Allowable Catch (TAC) is $80 \%$ of the existing potential, thus, the allowable catch is 8,331.94 tons.

Table 5 shows the utilization rate of banana prawn in the Rembang Regency from 2010 to 2018, where the highest sustainable potential value of $82 \%$ was obtained in 2014 , indicating full exploitation in 2014. The exploitation of fish resources is categorized as full in cases where the number of catches of fish resource groups per year is above $80 \%$ of the estimated potential set (PERMEN-KP No. 29 of 2012). Meanwhile, the average utilization rate is $44 \%$ of the potential value obtained, indicating moderate utilizatiuon. The exploitation of fish resources is categorized as moderate in cases where the number of the catch of fish resource groups per year is below 
$80 \%$ of the estimated potential set (PERMENKP No. 29 of 2012).

\section{CONCLUSION}

This study concluded banana prawn in the northern waters of Rembang Regency were caught using 2 types of fishing gear, and these are sotok or mini bottom trawls and trammel nets. As the main fishing gear in for catching the banana prawn, mini bottom trawl fishing gear construction measured in this study is $15.77 \mathrm{~m}, 16.5 \mathrm{~m}, 20.44 \mathrm{~m}$, and 25.2 $\mathrm{m}$, operated in fishing areas with a depth of 10-40 m, while the fishing season is from June to September. In addition, banana prawn resources in the northern waters of Rembang Regency have average stock density value of $16.22 \mathrm{~kg} / \mathrm{km}^{2}$ (range 4.37 to $41.14 \mathrm{~kg} / \mathrm{km}^{2}$ ), Cmsy value of $2.625 \mathrm{~kg}$, Emsy value of 4.172 trips and the average utilization rate of $44 \%$ (range 23 to $82 \%$ ).

\section{SUGGESTION}

Management policies in recovery and utilization efforts need to be implemented to create sustainable and sustainable fisheries, while environmentally-friendly fishing policies need to be developed. Furthermore, the implementation of these policies ought to be closely monitored by involving relevant agencies in Rembang Regency.

\section{ACKNOWLEDGEMENT}

The authors are grateful to all coastal communities of Rembang Regency and contributing related agencies, as well as the editors and managers of the Marine Fisheries Journal FPIK IPB, for reviewing the manuscript of this journal.

\section{REFERENCES}

Akoit MY, Mardit NN. 2018. Pengelolaan Sumberdaya Perikanan Berkelanjutan di Kabupaten Timor Tengah Utara Berbasis Bioekonomi. Jurnal Agribisnis Indonesia. 6(2): 85-108.

Ambarwati AS, Adi IR. 2019. Aksi Sosial Komunitas Nelayan Cantrang terhadap Kebijakan Larangan Penggunaan Alat Penangkapan Ikan. Journal of Social Welfare. 20(1): 13-29.
Amir MA, Dian W, Faik K. 2018. Analisis Bioekonomi Sumberdaya Ikan Pari (Dasyatis Sp.) di Perairan Rembang. Journal of Fisheries Resources Utilization Management and Technology. 7(4): 83-92.

Amron A, Mahdiana A, Haryono FED, Soedibya PHT. 2009. White Shrimp Population Intrinsic Growth Rate and Effort. Journal of Coastal Development. 12(3): 111-117.

Badan Standarisasi Nasional. 2006. Bentuk Baku Konstruksi Pukat Hela Arad. SNI 01-7233-2006.

Badriuzzaman D, Yulianto WT. 2014. Analisis Potensi Tangkap Sumber Daya Rajungan (Blue Swimming Crab) di Perairan Demak. Journal of Fisheries Resources Utilization Management and Technology. 3(3): 248-256.

Dajan A. 1983. Pengantar Metode Statistik Jilid 1. Jakarta: LP3ES.

Dewanti LP, Haidar F, Alexander K, Izza M, Heti H. 2019. Kepadatan Stok Ikan Demersal Menggunakan Alat Tangkap Dogol di Kabupaten Pangandaran. Albacore. 3(3): 241-248.

Department of Maritime Affairs and Fisheries of Rembang Regency. 2020a. Data Alat Penangkap Ikan di Kabupaten Rembang, Tahun 2011-2016.

Rembang.

$\begin{array}{ccc}\text { Perikanan } & \begin{array}{c}2020 \mathrm{~b} . \\ \text { Tangkap }\end{array} & \begin{array}{c}\text { Produksi } \\ \text { Kabupate }\end{array} \\ \text { Rembang, } & \text { Tahun } & 2010-2019 .\end{array}$

Rembang.

Grimm D, Barkhorn I, Festa D, Bonzon K, Boomhower J, Hovland V, Blau J. 2012. Assessing Catch Shares' Effects Evidence from Federal United States and Associated British Columbian Fisheries. Marine Policy. 36(3): 644657.

Hargiyatno IT, Anggawangsa RF, Sumiono B. 2015. Sebaran Spasio-Temporal Ukuran dan Densitas Udang Jerbung (Penaeus Merguiensis De Man, 1887) di Sub Area Dolak, Laut Arafura (WPPNRI 718). Jurnal Penelitian Perikanan Indonesia. 21(4): 261-269. 
Hart PJB, Reynolds JD. 2002. Handbook of Fish Biology and Fisheries. Oxford: Blackwell Publishing.

Ihsan H, Tajuddin M. 2019. Produksi Udang dan Pola Musim Penangkapannya di Perairan Kabupaten Pangkep. Journal of Indonesian Tropical Fisheries (JointFish): Jurnal Akuakultur, Teknologi dan Manajemen Perikanan Tangkap, IImu Kelautan. 2(1): 100-110.

Jamal M. 2015. Selektifitas Alat Tangkap Trammel Net Terhadap Udang Penaeid di Kabupaten Takalar Propinsi Sulawesi Selatan. Jurnal IImu Kelautan dan Perikanan. 25(2): 96-105.

Kartikaningtyas GC, Azis NB, Faik K. 2018. Analisis Perbandingan Pendapatan Nelayan Arad, Gill Net dan Trammel Net di Tambak Lorok Kota Semarang. Journal of Fisheries Resources Utilization Management and Technology. 7(3): 63-70.

Kementerian Kelautan dan Perikanan. 2016. Keputusan Menteri Kelautan dan Perikanan Republik Indonesia Nomor 79/KEPMEN-KP/2016 tentang Rencana Pengelolaan Perikanan Wilayah Pengelolaan Perikanan Negara Republik Indonesia 712.

2020. Peraturan Menteri Kelautan dan Perikanan Nomor 59 Tahun 2020 tentang Jalur Penangkapan Ikan dan Penempatan Alat Penangkapan Ikan di Wilayah Pengelolaan Perikanan Negara Republik Indonesia.

Ma'mun A, Priatna A, Suwarso S, Natsir M. 2018. Potensi dan Distribusi Spasial Ikan Demersal di Laut Jawa (WPPNRI712) dengan Menggunakan Teknologi Hidroakustik. Jurnal Ilmu dan Teknologi Kelautan Tropis. 10(2): 489-499.

Manadiyanto M, Sastrawidjaja S, Azizi A. 2017a. Pola Pemasaran Udang Laut (Penaeid) di Tuban, Jawa Timur. Jurnal Penelitian Perikanan Indonesia. 8(7): 67-80.

Manadiyanto M, Sastrawidjaja S, Pranowo SA, Sudarmanto T. 2017b. Analisis Ekonomi Usaha Penangkapan Udang Laut (Penaeid) dan Pemasarannya di Pantai Utara Jawa. Jurnal Penelitian Perikanan Indonesia. 8(7): 23-33.
Mosha EJ, Gallardo WG. 2013. Distribution and Size Composition of Penaeid Prawns, Penaeus Monodon and Penaeus Indicus in Saadan Estuarine Area, Tanzania. Ocean and Coastal Management. 82: 51-63.

Mustaruddin, Simbolon D, Khotib M. 2016. Pola Dinamis Penurunan Hasil Tangkapan Udang Akibat Pengendapan dan Limbah Industri di Kawasan Segara Anakan. Marine Fisheries. 7(2): 125-136.

Nurdin E, Kembaren DD. 2015. Parameter Populasi Udang Putih (Penaeus merguiensis) di Perairan Sampit dan Sekitarnya, Kalimantan Tengah. BAWAL Widya Riset Perikanan Tangkap. 7(2): 103-109.

Nurulludin N, Hidayat T, Mamun A. 2016. Kepadatan Stok Ikan Demersal dan Udang di Samudera Hindia Barat Sumatera pada Musim Peralihan II. Jurnal Penelitian Perikanan Indonesia. 22(3): 139-146.

Pezzuto PR, Alvarez-Perez JA, Wahrlich R. 2008. The Use of The Swept Area Method for Assessing the Seabob Shrimp Xiphopenaeus Kroyeri (Heller, 1862) Biomass and Removal Rates Based on Artisanal Fishery-Derived Data in Southern Brazil: Using Depletion Models to Reduce Uncertainty. Latin American Journal of Aquatic Research. 36(2): 245-257.

Prado J., Dreimere PY. 1990. Petunjuk Praktis Bagi Nelayan. Semarang: Balai Pengembangan Penangkapan Ikan.Direktur Jenderal Perikanan Tangkap

Sa'adah W, Milah K. 2019. Permintaan Udang Vannamei (Litopenaeus Vannamei) di Kelompok Pembudidaya Udang AtTaqwa Paciran Lamongan. Mimbar Agribisnis. 5(2): 243-251.

Saputra WS, Djuwito D, Rutiyaningsih A. 2013. Beberapa Aspek Biologi Udang Jerbung (Penaeus Merguiensis) di Perairan Pantai Cilacap Jawa Tengah. Journal of Management of Aquatic Resources. 2(3): 47-55.

Sasmita S, Martasuganda S, Purbayanto A. 2013. Perancangan Model untuk Pengujian Desain dan Konstruksi 
Cantrang Pantai Utara Jawa. Marine Fisheries. 4(1): 51-57.

Sibagariang OP, Fauziyah F, Fitri A. 2011. Analisis Potensi Lestari Sumberdaya Perikanan Tuna Longline di Kabupaten Cilacap, Jawa Tengah. Maspari Journal. 3(2011): 24-29.

Simbolon D, Budy W, Ika W, Hendro W. 2011. Tingkat Pemanfaatan dan Pola Musim Penangkapan Ikan Lemuru di Perairan Selat Bali. Buletin PSP. 19(3): 293-307.

Solihin I, Wisudo SH, Haluan J, Martianto D. 2011. Pengembangan Produksi Perikanan Tangkap di Wilayah Perbatasan (Kasus Kabupaten Nunukan Kalimantan Timur). Buletin PSP. 19(2): 9-18.

Sparre P, Venema SC. 1998. Introduction Tropical Fish Stock Assessment. FAO Fisheries Technical Paper. Rome.

Subagio H. 2019. Keragaman Musim Udang Penaeid yang Ditangkap Nelayan di Perairan Kota Surabaya. Prosiding Seminakel. 1(1).

Subani W, Barus HR. 1988. Alat Penangkap Ikan Laut dan Udang Di Perairan Indonesia. Jurnal Penelitian Perikanan Laut. Balai Penelitian Perikanan Laut Jakarta. (47): 21-30.

Sumiono B, Ernawati T, Suprapto. 2011. Kepadatan Stok Ikan Demersal dan Beberapa Parameter Kualitas Air di Perairan Tegal dan Sekitarnya. J.Lit.Perik.Ind. 17(2): 95 - 102.

Suruan S, Kondjol S, Toha M. Boli P. 2020. Identifikasi Hasil Tangkapan Nelayan Udang di Kampung Bakoi Kabupaten Sorong Selatan Provinsi Papua Barat. Jurnal Riset Perikanan dan Kelautan. 2(2): 212-224.

Tirtadanu T, Ernawati T. 2016. Kajian Biologi Udang Jerbung (Penaeus merguiensis DeMan, 1888) di Perairan Utara Jawa Tengah. Bawal Widya Riset Perikanan Tangkap. 8(2): 109-116.

Tirtadanu T, Suprapto S, Ernawati T. 2017. Laju Tangkap, Komposisi, Sebaran, Kepadatan Stok dan Biomasa Udang di Laut Jawa. J. Lit. Perik. Ind. 22(4): 243252.
Tirtadanu T, Panggabean AS. 2018. Catch Rate and Population Parameters of Banana Prawn Penaeus Merguiensis in Kaimana Waters, West Papua, Indonesia. AACL Bioflux. 11(4): 13781387.

Tirtadanu T, Suprapto S, Pane ARP. 2018. Komposisi Jenis, Sebaran dan Kepadatan Stok Udang pada Musim Selatan Di Perairan Timur Kalimantan. Bawal Widya Riset Perikanan Tangkap. 10(1): 41-47.

Tirtadanu T, Chodrijah U. 2020. Laju Tangkap, Karakteristik Biologi dan Status Pemanfaatan Udang Jerbung (Penaeus Merguiensis De Mann, 1988) dan Udang Dogol (Metapenaeus Affinis $\mathrm{H}$. Milne Edwards, 1837) di Perairan Cilacap. Jurnal Penelitian Perikanan Indonesia. 26(1): 47-58.

Umamah M, Sugeng HW, Ronny IW. 2017. Pengelolaan Sumber Daya Udang yang Berkelanjutan di Laut Aru dan Arafura. Albacore. 1(3): 245-255.

Umar MT, Andy Omar SB, Suwarni S. 2020. Study of Maximum Sustainable Yield of Rabbitfish (Siganus sp.) in Makassar Waters. Torani Journal of Fisheries and Marine Science. 3(2): 98-107.

Wijayanto D, Bambang AN, Ismail. 2013. Analisis Kelayakan Finansial Usaha Perikanan Tangkap dengan Alat Tangkap Trammel Net di Kabupaten Rembang. Semnas Riset dan Kebijakan Sosial Ekonomi Kelautan dan Perikanan 2013.

Wijayanto D, Setiyanto I, Setyawan HA. 2019. Bio-Economic Model of Danish Seine and Purse Seine fisheries in Rembang Regency. Egyptian Journal of Aquatic Research.

Wiyono ES. 2001. Optimasi Manajemen Perikanan Skala Kecil di Teluk Pelabuhanratu, Jawa Barat. [Tesis] Bogor. Institut Pertanian Bogor.

Zulfikar WG. 2020. Tren Harga Udang 2020, Bagaimana 2021?. Diunduh dari https://app.jala.tech/kabar_udang/tre n-harga-udang-2020-bagaimana2021 